\title{
APPLICATION OF THE INDICATOR ANALYSIS TO ASSESS AND IMPROVE THE QUALITY OF THE ASSEMBLY PROCESS OF TELECOMMUNICATIONS INSTALLATIONS - A CASE STUDY
}

\author{
Michał MOLENDA $^{1 *}$, Dominika PŁONKA ${ }^{2}$ \\ ${ }^{1}$ Silesian University of Technology, Faculty of Organization and Management, Institute of Economics \\ and Informatics; michal.molenda@polsl.pl, ORCID: 0000-0002-0276-742X \\ ${ }^{2}$ Silesian University of Technology, Faculty of Organization and Management, Institute of Economics and \\ Informatics; dominika.plonkaa@gmail.com, ORCID: 0000-0002-9328-1838 \\ * Correspondence author
}

Purpose: The aim of the paper is to present a case of effective application of the indicator analysis to assess and improve the process of installing a fiber optic Internet network installation at the customer's site. The processes carried out outside the company's headquarters, in particular their limited possibility of supervision and direct contact with the customer, cause these processes to require a special approach to management.

Design / methodology / approach: The assessment of the installation process was carried out by means of the indicator analysis. The key indicators and their target values were obtained on the basis of research conducted in one of the telecommunications companies. The assessment of the quality and efficiency of the process and the effectiveness of improvement actions was based on observations and analysis of data from the company's reports from 2017 and 2019. The theoretical scope of the work concerns methods of improving the quality and efficiency of manufacturing processes.

Findings: The research process identified a set of indicators that can be used to assess the process of installation of systems in the examined company or similar ones. The quality and efficiency of the analyzed process was evaluated. The key factors determining these process properties were identified, owing to which it was possible to determine the necessary improvement actions to be implemented in the examined organization. A comparative analysis was conducted to assess the effectiveness of the implemented solutions.

Practical implications: The study allowed to broaden the knowledge about the analyzed process in terms of methods of its measurement and factors having a decisive influence on its quality and efficiency. The process under analysis has been effectively improved.

Originality / value: Application of the indicator analysis to a process with limited supervisory capabilities, key impact on customer satisfaction and business costs. The paper is addressed to the managerial staff of telecommunications companies involved in the installation of Internet network systems outside the company's headquarters. The paper contains identified indicators of the assembly process and factors, mainly organizational ones, affecting its characteristics.

Keywords: KPI, Key Performance Indicators, improvement, process management, Lean.

Category of the paper: Case study. 


\section{Introduction}

One of the basic tasks of the managerial staff aiming at achieving proper level of efficiency and competitiveness of the company is to monitor and improve the processes. One of the basic tools for diagnosing organizational processes is indicator analysis. This paper presents a case of using indicator analysis to evaluate and improve the quality and efficiency of the industrial process carried out by one of the telecommunications companies operating in Poland. The company, as part of its services, carried out the process of installation of Internet access via fiber optic network in the customer's facilities. Due to high costs of assembly processes and a high number of complaints, the management of the company decided to implement an improvement program. The case described in this paper is a good example of the effectiveness of using indicator analysis to assess the quality and efficiency of industrial processes.

The first part of the paper describes the results of the literature research in the field of analysis and improvement in the quality and efficiency ratio of the organization. The main part of the paper contains the results of a study aimed at assessing the quality and efficiency of the assembly process. The evaluation of the process was carried out on the basis of a specially developed set of indicators for this purpose. The indicators were used to assess the quality of the assembly process before and after the implementation of improvement changes. Data for evaluation was collected in the first 6 months of 2017 and 2019. Owing to this, it was possible to compare the quality and effectiveness of the analyzed process and assess the effectiveness of the undertaken improvement measures. In the paper, the reader will find the answer to 3 basic questions: how effectively the quality and efficiency of the process of assembling a telecommunications installation in the surveyed company was measured, what target values of the indicators were set and what factors affected the quality and efficiency of the analyzed process.

\section{Improvement of the organization based on key performance indicators}

One of the basic problems solved by the science of management is the efficiency of operation of a company. Efficiency ensures its existence, constitutes the basis for its development and a starting point for shaping its market position. Among many categories of efficiency considered in the literature, the dominant one is the concept of system functioning efficiency (e.g. organizational), which means the ability of a company to adapt to current and strategic changes in the environment and to use its resources productively to achieve the adopted structure of objectives (Szymańska, 2010). 
Therefore, evaluating and improving the efficiency of company processes has now become the main task of today's managers. Without proper diagnostics in the area of efficiency and continuous improvement of business processes, it is difficult to imagine a lasting market success of a company today. The role of improvement is highlighted in many scientific and practical publications. Continuous improvement of the organization is not only a function of normative management systems (Biały, and Hąbek, 2016; Ligarski, 2010; Midor, 2010, 2013), but also a condition for competitiveness and existence of companies on the market. The best evidence of the need to improve the companies in the area of efficiency is the popularity of the Lean Management concept in company management. Many scientific and practical studies have been produced concerning the Lean concept. It is currently used in all industries, such as the automotive industry (Midor, 2017), the mining industry (Stecuła et al., 2017) and the metals industry (Wolniak, and Skotnicka-Zasadzień, 2014). The application of the Lean concept is also not limited in terms of process types. Lean tools are used to evaluate and improve production, service, machinery maintenance (Zasadzień, 2015) and logistics processes (Molenda, and Lach, 2014). In this context, it is not surprising that the Lean concept has been supported by the IT environment (Wojtaszak, and Biały, 2013).

Improvement in the area of efficiency requires a comprehensive diagnosis of the organization. The difference between the effects and the means incurred to achieve them consists in economic efficiency, which, having a key importance for the stakeholders, determines the basis for the existence and development of the company and fundamentally affects the achievement of benefits by the owners. Modern methods of measuring efficiency use, among others, the indicator approach - they use indicators of profitability, costeffectiveness and productivity. Key Performance Indicators (KPIs) - "are financial and nonfinancial indicators used as indicators in the processes of measuring the degree of achievement of the organization's objectives" (Maruszewska, and Biały, 2017; Biały, and Hąbek, 2016). They provide an opportunity for continuous evaluation of the company's operations, improving its performance, acquiring knowledge, and helping managers to define and achieve operational and strategic goals (Bitkowska, 2015). Designing performance indicators depends on the type of organization, its size, industry and its specific features. The key to the method of selecting the desired KPIs is to correctly define the values to be achieved (Grabowska, 2017). An instrument for combating adverse consequences of events occurring within the company, their prevention and a means for the development of the organization is the implementation of a system of indicators of process efficiency. A properly defined system of indicators is used to achieve the organization's operational assumptions related to the company's long-term plans. 


\section{Diagnosis of the system installation process}

The course of the assembly process of a fiber optic system is shown in Fig. 1.

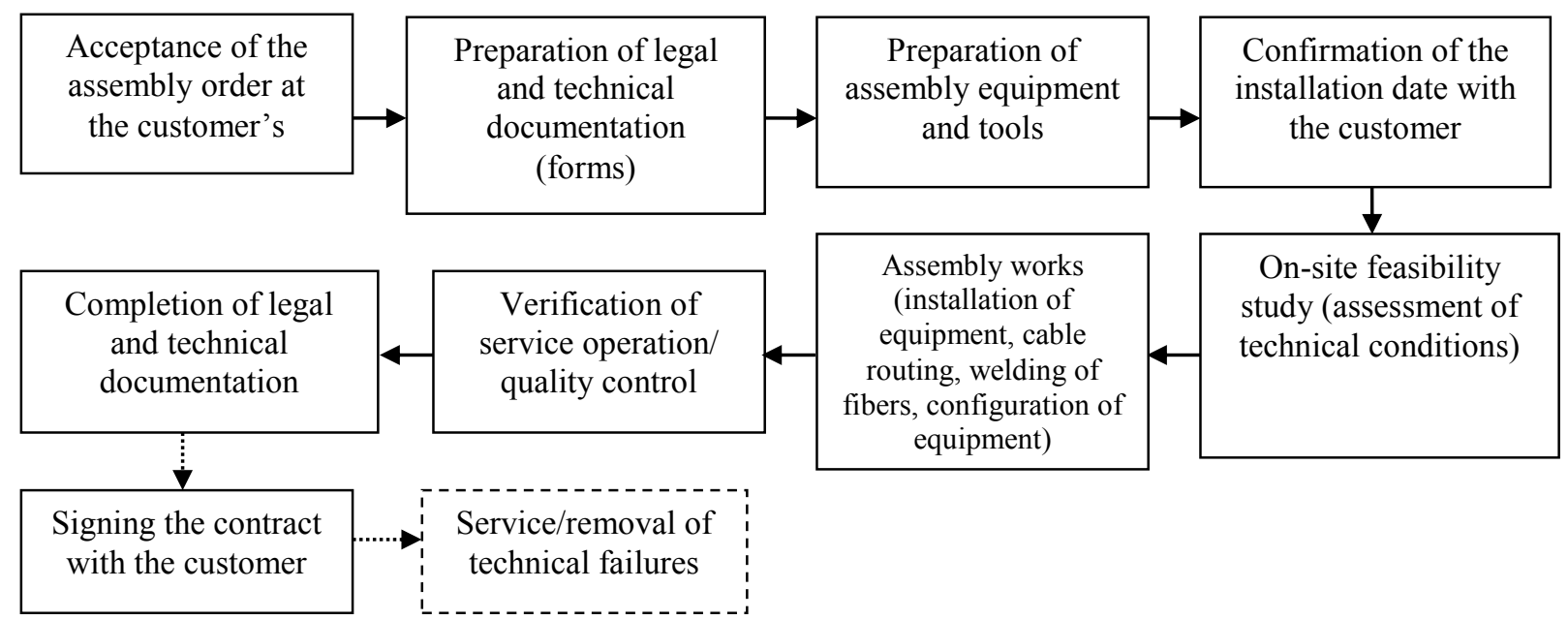

Figure 1. An overview map of the assembly process of a telecommunications installation. Source: own study.

The examination of the original state of the assembly process, based on a specially developed set of indicators, was carried out using data collected between January and June 2017. The results of the tests allowed to illustrate the original state of the organization and problems with quality assurance and process efficiency. The results were used to propose and implement a number of organizational and procedural changes aimed at improving the analyzed process. Based on the data collected between January and June 2019, the assembly process was reassessed. The indicator method made it possible to realistically determine to what extent the improvement changes affected the quality and efficiency of the work performed. Table 1 contains a set of key indicators in the framework of which the assembly process was diagnosed.

Table 1.

Indicators for evaluating the assembly process of a telecommunications installation

\begin{tabular}{|c|c|c|c|}
\hline id. & Indicator name & Indicator & $\begin{array}{l}\text { Unit of } \\
\text { measurement }\end{array}$ \\
\hline$\# 1$ & $\begin{array}{l}\text { Failure rate after } \\
\text { installation }\end{array}$ & $=\frac{\text { Number of failures reported within a month since installation }}{\text { Number of complete installations in a month }} \times 100 \%$ & $\%$ \\
\hline$\# 2$ & $\begin{array}{l}\text { Number of } \\
\text { installations } \\
\text { which do not } \\
\text { come into effect }\end{array}$ & $=\frac{\text { Number of installations not performed by the installers after arriving }}{\text { Number of complete installations in a month }}$ & $\%$ \\
\hline$\# 3$ & Installation cost & $\begin{array}{l}=\text { Average cost of materials per installation }+[(\operatorname{cost} \text { per work hour } \mathrm{x} \\
\text { average installation time }) \times 2]\end{array}$ & PLN \\
\hline$\# 4$ & $\begin{array}{l}\text { Documentation } \\
\text { errors }\end{array}$ & $=\frac{\text { Number of documentation errors related to assembly }}{\text { Number of complete installations in a month }} \times 100 \%$ & $\%$ \\
\hline
\end{tabular}


Cont. table 1.

\begin{tabular}{|c|c|c|c|}
\hline$\# 5$ & $\begin{array}{l}\text { Number of } \\
\text { cancellations up } \\
\text { to } 14 \text { days due } \\
\text { to connection } \\
\text { failure }\end{array}$ & $=\frac{\text { Number of contract withdrawals }}{\text { Number of complete installations in a month }} \times 100 \%$ & $\%$ \\
\hline \#6 & $\begin{array}{l}\text { Number of } \\
\text { installations per } \\
\text { month per } \\
\text { assembly team }\end{array}$ & $=\frac{\text { Number of complete installations in a month }}{\text { Number of assembly teams }}$ & pcs/team \\
\hline \#7 & $\begin{array}{l}\text { Average } \\
\text { installation time }\end{array}$ & $=\frac{\text { Total working time of assembly teams }}{\text { Number of complete installations }}$ & $\mathrm{h} /$ assembly \\
\hline
\end{tabular}

Source: own study.

Indicator \#1 takes into account the failures reported by the customer after the installation. They included cases related to:

- Incorrectly routed wiring (abrasions, breakdowns affecting signal loss),

- an ill-considered location for mounting the equipment,

- errors or omissions in the configuration of access devices and client devices (e.g. nonrecognition or incorrect recognition of network card parameters).

Indicator \#2, describing the number of installations that do not take effect, describes a situation in which the assembly team at the customer's site fails to effectively carry out the installation. Such cases took place for objective reasons (weather conditions), organizational errors (incorrect recognition of technical conditions), as well as employee shortcomings (delays, lack of equipment).

The cost of installation (\#3) consisted mainly of the cost of materials used (cabling, sockets, patch cords, cables, terminals), working hours, fuel, vehicle depreciation.

The scope of indicator \#4 describing the number of errors in the documentation related to the installation consisted in particular:

- misspelled personal data,

- incorrectly entered geolocation data,

- incorrectly entered information about the service package (incorrectly assigned speed, activation fee, discount),

- lack of signatures of the subscriber on the contract,

- incomplete contracts,

- no acceptance protocol for assembly,

- no protocol for speed tests on client devices,

- no approvals were obtained for the right to route the cabling over the adjacent land.

Factors determining the exercise of the right of withdrawal (\#5) were mainly: failure of the connection, lack of response to the service request, accounting errors. The remaining indicators (\#6 and \#7) take into account data from the working time register. 


\section{Indicator analysis - initial state}

The results of the indicator analysis in the first 6 months of 2017 and the established target values are summarized in Table 2.

Table 2.

Results of the indicator analysis of the examined process - initial state

\begin{tabular}{|c|c|c|c|c|c|c|c|c|c|}
\hline \multirow[t]{3}{*}{ ID. } & \multirow[t]{3}{*}{ Indicator name } & \multicolumn{6}{|c|}{ Results obtained in the first half of 2017} & \multirow[t]{3}{*}{ Objective } & \multirow[t]{3}{*}{$\mathbf{U M}$} \\
\hline & & \multicolumn{6}{|c|}{ Value } & & \\
\hline & & $\begin{array}{c}\text { January } \\
2017\end{array}$ & $\begin{array}{c}\text { February } \\
2017\end{array}$ & $\begin{array}{l}\text { March } \\
2017\end{array}$ & $\begin{array}{l}\text { April } \\
2017\end{array}$ & $\begin{array}{l}\text { May } \\
2017\end{array}$ & $\begin{array}{l}\text { June } \\
2017\end{array}$ & & \\
\hline \#1 & $\begin{array}{l}\text { Failure rate after } \\
\text { installation }\end{array}$ & $43.9 \%$ & $43.5 \%$ & $42.5 \%$ & $40.9 \%$ & $41.5 \%$ & $40.4 \%$ & $\max .7 .00$ & $\%$ \\
\hline \#2 & $\begin{array}{l}\text { Number of installations } \\
\text { which do not come into } \\
\text { effect }\end{array}$ & $18.4 \%$ & $20.0 \%$ & $18.5 \%$ & $17.0 \%$ & $18.9 \%$ & $19.3 \%$ & $\max .8 .00$ & $\%$ \\
\hline \#3 & Average installation cost & 642 & 628 & 646 & 609 & 664 & 638 & $\max .565$ & PLN \\
\hline$\# 4$ & Documentation errors & $17.0 \%$ & $16.9 \%$ & $16.6 \%$ & $18.0 \%$ & $17.5 \%$ & $18.4 \%$ & $\max .2 .00$ & $\%$ \\
\hline$\# 5$ & $\begin{array}{l}\text { Number of cancellations up } \\
\text { to } 14 \text { days due to connection } \\
\text { failure }\end{array}$ & $4.1 \%$ & $4.3 \%$ & $3.7 \%$ & $3.3 \%$ & $3.9 \%$ & $4.9 \%$ & $\max .1 .5$ & $\%$ \\
\hline \#6 & $\begin{array}{l}\text { Number of installations per } \\
\text { month per installation team }\end{array}$ & 84 & 80 & 92 & 76 & 84 & 84 & $\min .65$ & $\begin{array}{l}\text { pcs./ } \\
\text { team }\end{array}$ \\
\hline \#7 & Average installation time & 2 & 2 & 2 & 2 & 2 & 2 & $\max .3-4$ & $\begin{array}{l}\mathrm{h} / \\
\text { installa- } \\
\text { tion }\end{array}$ \\
\hline
\end{tabular}

Source: own study.

The indicator analysis showed that 5 of the examined indicators remained outside the limits of the set objectives throughout the whole period under consideration. The indicator (\#1) of assembly failure rate was exceeded almost 6 times in each month. The failure rate not only affects the efficiency of the process due to the need for costly troubleshooting, but also has a particularly negative impact on customer feedback. Indicators (\#2) of the number of installations that do not come into effect remained within the range of $17 \%-20 \%$ and more than doubled the set target. Such a state of affairs was painful for the surveyed company, in particular due to the so-called "empty runs" of the installation teams, which generate unnecessary costs. During the implementation period of the projects, high prices of components (equipment and cabling), prices of project services and official fees, as well as charges for the use of foreign infrastructure resulted in a clear underestimation of expenditure. The average cost of installation (\#3) was exceeded by $12 \%$ on average. Indicator (\#4), the number of errors in documentation was exceeded by over $15 \%$ each month. The lack of a uniform contract form, combined with the high mobility of employees and the lack of support for the IT system, were conducive to making formal errors in the documentation. The situation was aggravated by the training system in this area, which was not adapted to the high turnover of employees. The long time of waiting 
for the removal of the defect and the number of recorded failures directly affected the indicator (\#5) of withdrawal from the contract (by $4.02 \%$ on average). The high demand for service and pricing policy has translated into a large number of installations (\#6). Throughout the entire analyzed period, the assumed objectives were significantly exceeded (by more than $20 \%$ ). This was also influenced by the commission system and the imposed minimum number of connections to be implemented by the team. The large number of installation orders completed caused the average time of their completion (\#7) to turn out to be quite low in relation to the assumed target. The last two indicators are within the limits of the objectives set. Unfortunately, as is often the case, quantity and speed were not accompanied by such features as quality and efficiency.

\section{Description of improvement measures}

The evaluation of the installation process on the basis of an indicator analysis led to the decision to carry out an audit to look for reasons for the lack of efficiency and quality. Based on the results of the audit, the top management decided to introduce a number of changes, in particular procedures to standardize the installation process. Based on the procedures, individual activities were redefined, their scope, sequence, responsibilities (subject matter, reporting, supervision, corrections) and employees' responsibility for entrusted tasks were defined or specified. Scheduling of installation work and checklists have been introduced, and the installation department has been instructed to fill them in according to the actual state of affairs. The purpose of the list is to conduct a statistical survey, self-correction of the employee to systematize and archive the course of the installation and control the work by the supervision department (correction of actions inconsistent with the procedure and omissions, as well as introduction of changes optimizing the process).

Technical training in the field of theoretical knowledge was introduced, combined with practical classes, which were given a cyclical character. The training is divided into stages the transition to the next one requires an internal certificate issued by the department leader. The aim is to improve substantive preparation and increase self-control and employee competence. This allows the installer to diagnose problems and solve them already at the stage of first contact with the customer. Moreover, the principle of supporting the assembly process by other departments of the company has been introduced. As a result, the time of removing the defect is shortened and the effectiveness of the employee is increased.

Taking into account the needs of customers and to increase competitiveness, the working time was reorganized by introducing evening and weekend duty. 
The order and delivery system was reorganized, a unit responsible for testing equipment before it is introduced into the network was established, and technical solutions ensuring its continuous monitoring were implemented.

The changes described above would not be effective if they were not accompanied by a change in attitude and awareness of the staff. In order to reduce the resistance to staff change, a specially formed team of staff leaders was involved in the change process, in particular, they participated in theoretical and practical training, as well as competence tests. A set of operational procedures was developed and implemented, including changes in the organizational structure, and the way of management was modified. The changes also involved additional investments (modernization of workstations, purchase of equipment, purchase or development of own software). First of all, operational procedures were developed and implemented, which determined the most effective method of performing work. Owing to them, the knowledge was systematized and mechanisms for its "storage" were created. The standards caused the subjectivity of work evaluation to give way to objective factors (adoption of schemes, check-lists). They made it possible to determine the cause-effect relationship and indicate the source of inefficiency. The procedures have also served to maintain and raise the appropriate level, standardize activities, they became a tool of control and cognition, fostered internal communication, stimulated creativity, defined the powers of staff.

\section{Evaluation of the effectiveness of the implemented changes}

In order to check the impact of the changes on the efficiency of work in the customer connections department, a similar efficiency test was carried out with the same indicators. Such an analysis will allow for a realistic assessment of the impact of changes on the quality and efficiency of the analyzed process. The process of installing a fiber optic connection in the light of the organization is considered to be one of the key elements due to the long-term effects on the main costs generated in the organization and its perception by customers.

Table 3.

Comparison of indicators received after the implementation of the changes.

\begin{tabular}{|c|c|c|c|c|c|c|c|c|c|}
\hline \multirow[t]{3}{*}{ ID. } & \multirow[t]{3}{*}{ Indicator name } & \multicolumn{6}{|c|}{ Results obtained in the first half of 2017} & \multirow[t]{3}{*}{ Objective } & \multirow[t]{3}{*}{$\mathbf{U M}$} \\
\hline & & \multicolumn{6}{|c|}{ Value } & & \\
\hline & & $\begin{array}{c}\text { January } \\
2019\end{array}$ & $\begin{array}{c}\text { February } \\
2019\end{array}$ & $\begin{array}{l}\text { March } \\
2019\end{array}$ & $\begin{array}{r}\text { April } \\
2019\end{array}$ & $\begin{array}{l}\text { May } \\
2019\end{array}$ & $\begin{array}{l}\text { June } \\
2019\end{array}$ & & \\
\hline$\# 1$ & Failure rate after installation & $7.28 \%$ & $7.54 \%$ & $6.67 \%$ & $6.30 \%$ & $6.19 \%$ & $5.78 \%$ & $\max .7 .00$ & $\%$ \\
\hline \#2 & $\begin{array}{l}\text { Number of installations which } \\
\text { do not come into effect }\end{array}$ & $9.38 \%$ & $7.01 \%$ & $8.21 \%$ & $7.97 \%$ & $6.42 \%$ & $7.34 \%$ & $\max .8 .00$ & $\%$ \\
\hline
\end{tabular}


Cont. table 3.

\begin{tabular}{|c|c|c|c|c|c|c|c|c|c|}
\hline \#3 & Average installation cost & 554 & 698 & 557 & 528 & 479 & 543 & $\max .565$ & PLN \\
\hline \#4 & Documentation errors & $1.92 \%$ & $1.83 \%$ & $2.28 \%$ & $2.17 \%$ & $1.99 \%$ & $1.71 \%$ & $\max .2 .00$ & $\%$ \\
\hline$\# 5$ & $\begin{array}{l}\text { Number of cancellations up to } \\
14 \text { days due to connection } \\
\text { failure }\end{array}$ & $1.15 \%$ & $1.02 \%$ & $0.88 \%$ & $1.18 \%$ & $0.88 \%$ & $0.86 \%$ & $\max .1 .5$ & $\%$ \\
\hline \#6 & $\begin{array}{l}\text { Number of installations per } \\
\text { month per installation team }\end{array}$ & 72 & 66 & 69 & 69 & 69 & 63 & $\min .65$ & $\begin{array}{l}\text { pcs./ } \\
\text { team }\end{array}$ \\
\hline \#7 & Average installation time & 2.67 & 2.67 & 2.67 & 2.67 & 2.67 & 2.67 & $\max .3-4$ & $\begin{array}{l}\mathrm{h} / \\
\text { installa- } \\
\text { tion }\end{array}$ \\
\hline
\end{tabular}

Source: own study.

The results of the indicator analysis of the data included in Table 3 clearly show that the scope of the introduced changes has allowed to achieve a significant improvement in the quality and efficiency of the assembly process. Although in the first months of 2019 the failure indicators (\#1) slightly exceeded the target value, the improvement changes had a very positive impact on this process parameter. Figure 2 compares the installation failure indicators in 2017 and 2019.

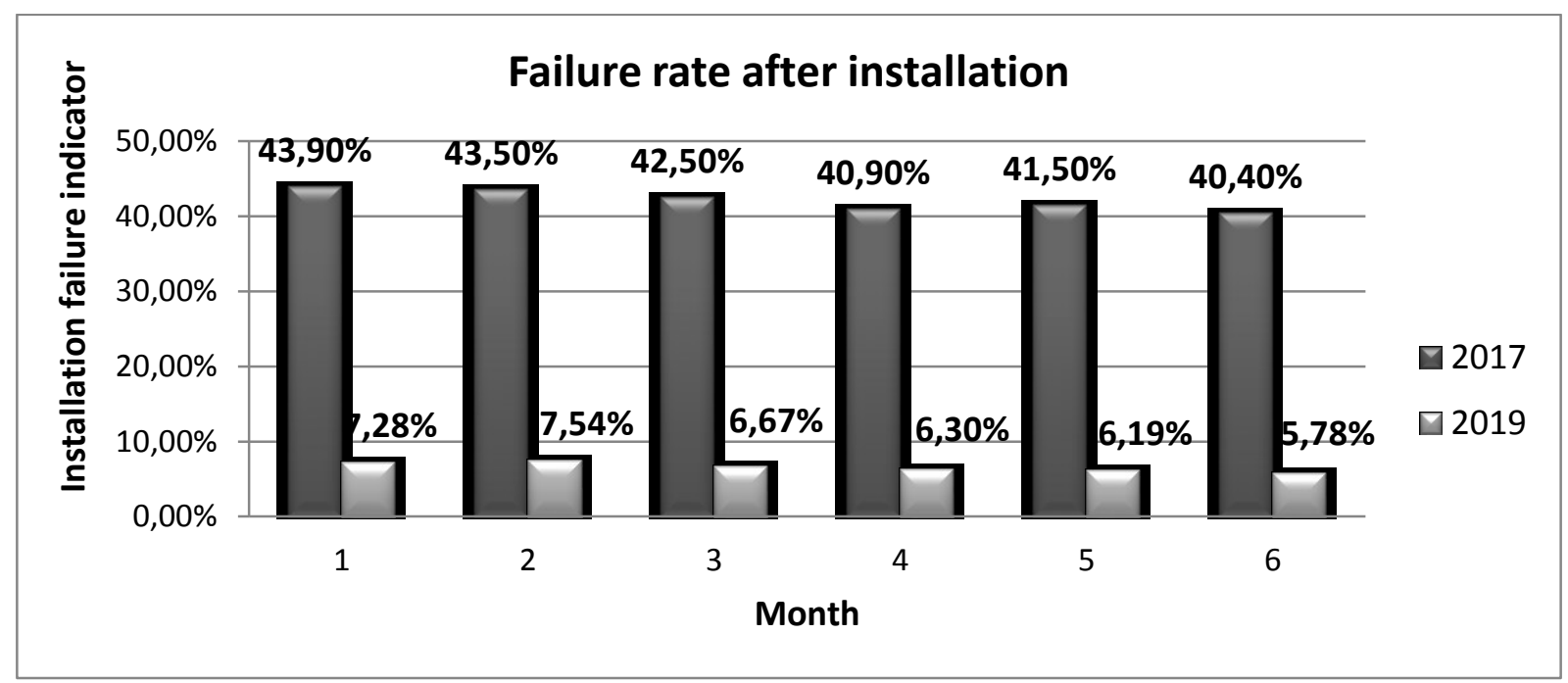

Figure 2. Failure rate after installation. Source: own study.

The exceeded values of the indicator (\#2) of the number of installations not completed in January and March were due to unfavorable weather conditions during those periods, which in many cases - prevented installation.

Indicator (\#3) of installation cost in February 2019 alone was outside the target. In this case, it was again influenced by objective circumstances, independent of the company's work. It was an increase in equipment prices, mainly due to the change in foreign exchange rates. Improvement changes caused a significant decrease in the number of errors in documentation (\#4). March and April 2019 are the only periods, in which the maximum level (2\%) of errors in documentation was exceeded. Figure 3 shows a comparison of this indicator in the examined periods. 


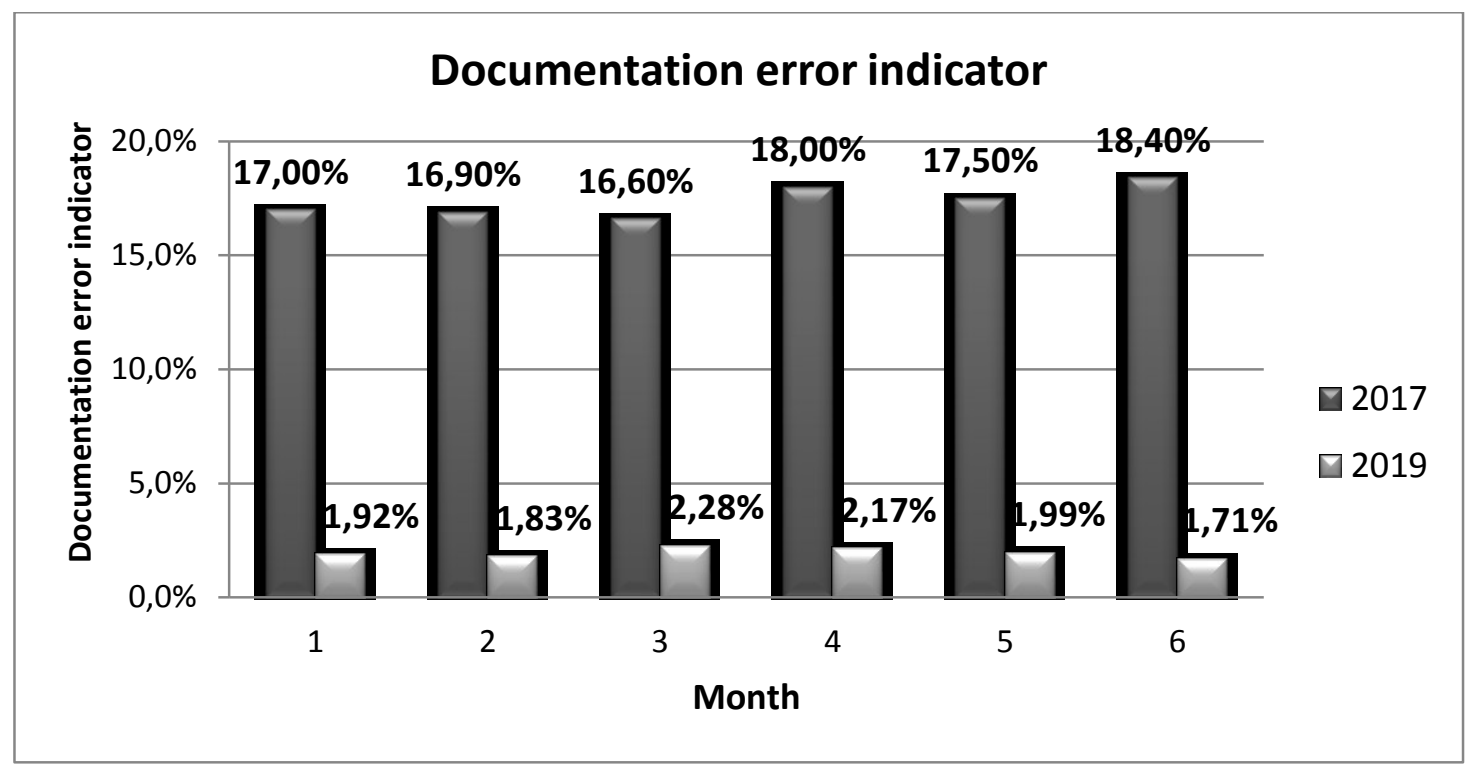

Figure 3. Documentation error indicator. Source: own study.

In Figure 4, a comparison was made of the customer cancellation indicators (\#5) during the test period, i.e. up to 14 days from the date of installation. The level of acceptance of this indicator was set at a maximum of $1.5 \%$. In the whole analyzed period of 2019 it was not exceeded. Improvement activities in the form of implementation of assembly procedures should be assessed as effective. The objectives were achieved by introducing standards for the way the connection is made and its protection against abrasion, accidental breakdowns, damage by animals and the forces of nature. The use of proper tools, equipment, means and sequence of actions (cleaning and cutting the fiber) or the use of mechanical welds without the control of the so-called light leaks improved the quality of assembly, as well as the number of cancellations during the test period.

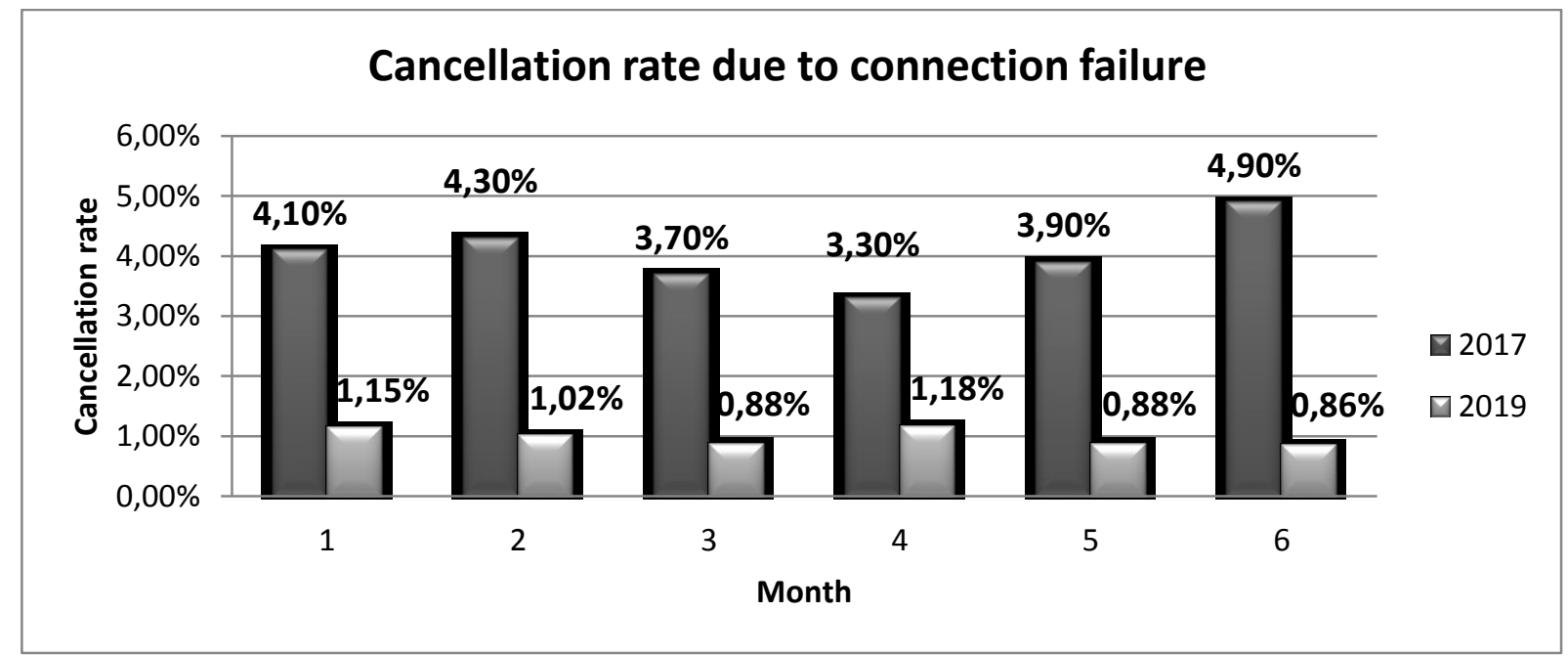

Figure 4. Cancellation rate due to connection failure. Source: own study.

After the implementation of improvement changes, the number of installations implemented by the installation team (\#6) in the test period did not reach the assumed target (min. 65 pieces) only in June. The introduced procedural changes resulted in the average number of works carried out by the installation teams falling in comparison with the period in 2017 . The average 
installation time was also extended (\#7). Although these changes may seem unfavorable, they are an inevitable consequence of the implemented changes, in particular the focus on the robustness and reliability of the implemented installation and high customer satisfaction. The next stage of changes in the surveyed company should be working on operational excellence and improvement of these indicators.

\section{Conclusions}

The paper describes a case of improving the installation process of telecommunication systems in one of the selected companies operating in Poland. The collected data from the first half of 2017 was analyzed with the help of a specially developed set of 7 indicators and established target values. The results of the indicator analysis revealed the scale of problems with the quality and efficiency of the analyzed process. This resulted in a decrease in customer satisfaction and high operating costs. This has led the management of the company to implement fundamental improvement changes. The changes in the company were very radical, among others:

- introduction of monitoring of quality and efficiency indicators of the assembly process,

- change in the awareness of the company's staff in terms of the importance of meeting customer requirements,

- change in the approach to training of installers,

- development and implementation of operational procedures, detailing the responsibility for quality,

- change in the rules for testing equipment before installation,

- standardization of documentation (forms, prints) created during the installation,

- change of the reporting rules on the implementation of the installation process, in particular on technical problems,

- change of the rules of removing technical problems and failures,

- change of the rules of cooperation in the company aimed at extending the scope of responsibility for quality to other departments of the company.

The analysis of the data collected in the first half of 2019 revealed high effectiveness of the training. Most of the indicators have improved significantly and are now at an acceptable level. The applied indicator analysis, together with a number of changes in the organization, is a good example of an effective improvement process, especially with regard to processes, whose supervision is limited and which are crucial for customer satisfaction. 


\section{References}

1. Biały, B., Hąbek, P. (2016) Doskonalenie procesu produkcji poprzez analizę zwrotów gwarancyjnych, [in:] Kvalita, technologie, diagnostika v technickych systemoch. Quality, technologies, diagnostics of technical systems. Zbornik vedeckych prac. Slovenska Požnohospodárska Univerzita v Nitre, Nitra, pp. 12-20.

2. Biały, W., Hąbek, P. (2016) The application of OEE indicator to evaluate the use of a machine - case stud. Syst. Wspomag. Inż. Prod. z. 2, pp. 55-65

3. Bitkowska, A. (2015). Rola mierników efektywności procesów w perspektywie zarządzania wiedzą. Przegląd Organizacji, $n r$, pp. 22-27.

4. Grabowska, S. (2017) Key performance indicators - case study. Zesz. Nauk. PŚl., Org. Zarz., z. 108, pp. 105-111.

5. Ligarski, M.J. (2010) Podejście systemowe do zarządzania jakościa w organizacji. Gliwice: Wyd. Politechniki Śląskiej.

6. Maruszewska, E., Biały, W. (2017) Financial challenges in production engineering using key performance indicators - a case of different production process types. Syst. Wspomag. Inż. Prod. vol. 6 iss. 4, pp. 41-48.

7. Midor, K. (2010). Metody zarządzania jakością w systemie WCM, studium przypadku, [w:] J. Żuchowski (ed.), Zarządzanie jakościa wybranych procesów. Wydawnictwo Naukowe Instytutu Technologii Eksploatacji w Radomiu. nr 1.

8. Midor, K. (2013). An innovative approach to the evaluation of a quality management system in a production enterprise. Scientific Journals Maritime University of Szczecin, No. 34.

9. Midor, K. (2017). Use of Six Sigma in the production process - case study, [in:] M.J. Ligarski (ed.), Systems supporting production engineering, vol. 6, iss. 4. Gliwice: P.A. NOVA, pp.147-152.

10. Molenda, M., Lach, N. (2014). Proces wdrażania innowacji w postaci kontroli wizualnej doskonalącej procesy logistyczne, [in:] J. Kaźmierczak, J. Bartnicka (eds.), Zarządzanie innowacjami w produkcji i ustugach (pp. 182-190). Opole: Oficyna Wydaw. Polskiego Towarzystwa Zarządzania Produkcją.

11. Stecuła, K., Tutak, M., Brodny, J. (2017). Application of chosen elements from Japanese production and maintenance management philosophies in Polish coal mines. In: 17th International Multidisciplinary Scientific GeoConference SGEM. Conference proceedings Vol. 17, Science and technologies in geology, exploration and mining. Iss. 13 - Exploration and mining. Sofia: STEF92 Technology, pp. 93-100.

12. Szymańska, E. (2010). Efektywność przedsiębiorstw - definiowanie i pomiar. Roczniki Nauk Rolniczych, seria G.T.97. z. 2, pp. 156-159. 
13. Wojtaszak, M., Biały, W. (2013). Measurement system analysis of attribute or continuous data, as a one of the first steps in Lean Six Sigma projects, [in:] J. Kaźmierczak (ed.), Systems supporting production engineering (pp. 144-162). Gliwice: P.A. NOVA.

14. Wolniak, R., Skotnicka-Zasadzień, B. (2014). The use of value stream mapping to introduction of organizational innovation in industry. Metalurgija, vol. 53, iss. 4, pp.709712.

15. Zasadzień, M. (2015). The effect of implementation maintenance cards in performance of machines in selected production company. Management Systems in Production Engineering, No. 4(20), pp. 225-229. 